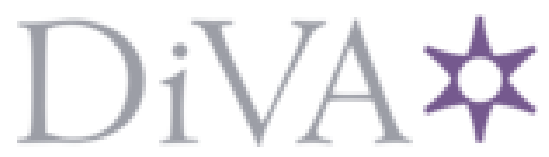

http://www.diva-portal.org

This is the published version of a paper published in Socialvetenskaplig tidskrift.

Citation for the original published paper (version of record):

Lundgren, M., Blom, B., Morén, S., Perlinski, M. (2009)

Från integrering till specialisering: om organisering av socialtjänstens individ- och familjeomsorg 1988-2008.

Socialvetenskaplig tidskrift, (2): 162-183

Access to the published version may require subscription.

N.B. When citing this work, cite the original published paper.

Permanent link to this version:

http://urn.kb.se/resolve?urn=urn:nbn:se:umu:diva-26094 


\title{
Från integrering till specialisering - om organisering av socialtjänstens individ- och familjeomsorg 1988-2008
}

\section{MINNA LUNDGREN, BJÖRN BLOM, STEFAN MORÉN \& MAREK PERLINSKI}

\begin{abstract}
Individ-och familjeomsorgen i Sveriges kommuner har under de senaste tjugo åren gått frän ett mer generalistiskt orienterat arbetssätt till en organisation med specialiserade arbetsgrupper. I den här artikeln visar vi på olika former av specialisering och redovisar en kartläggning över hur det ser ut i kommunerna idag. Vi diskuterar också möjliga anledningar till förändringen.
\end{abstract}

\section{Bakgrund}

I Sverige är det kommunerna som har det

Minna Lundgren, fil.kand./socionom, Östersunds kommun.

Björn Blom, professor i socialt arbete, Umeå universitet.

Stefan Morén, professor i socialt arbete, Umeå universitet.

Marek Perlinski, universitetsadjunkt i socialt arbete, Umeå universitet. yttersta ansvaret för att hjälpa människor som befinner sig i socialt utsatta situationer. Men vilken hjälp som skall ges, hur den skall utformas, och hur arbetet skall organiseras är inte reglerat i detalj och kommunerna har en relativt stor frihet att själva organisera den sociala servicen enligt lokala förutsättningar (Socialtjänstlagen 2 kap 4§, Kommunallagen 3 kap 4 §). Trots socialtjänstlagens formulering om alla människors rätt till lika behandling vid en bedömning av deras hjälp- 
behov, kan skillnader i kommunernas sätt att organisera individ- och familjeomsorgen leda till att behoven bedöms olika beroende på vilken kommun man bor i (Byberg 2002, Minas 2005, Stranz 2007).

När den nya socialtjänstlagen utarbetades under 1970-talet var ledordet helhetssyn. Med helhetssyn menades att individens hela problemsituation skulle belysas, att man skulle ta i beaktande inte bara individens problem, utan hela det sammanhang individen befinner sig $i$. Man framhöll att socialtjänstens organisation inte längre skulle byggas upp enligt symptomprincip (eller i enlighet med de gamla barnavårds-, socialhjälps- och nykterhetsvårdlagarna), utan socialarbetarna förväntades fungera som generalister och arbeta med alla typer av sociala problem (SOU 1974:39). Helhetssynens prägel på organisationen hade också sin grund i att man ville undvika den sociala stigmatisering det innebar att kategorisera människor och deras problem. Klienterna skulle dessutom bara behöva ha kontakt med en socialarbetare (Bergmark \& Lundström 2005).

I slutet av 1980-talet började den integrerade organisationsmodellen att utsättas för kritik. Man menade att individ- och familjeomsorgen (IFO) istället kunde organiseras utifrån principen att samarbeta med kollegor och instanser med bättre kunskaper. Genom en specialisering av IFOs arbetsområde skulle klienterna få möta socialarbetare med högre kompetens inom sitt arbetsområde (Bergmark \& Lundström 2005). I socialtjänstutredningen från 1999 (SOU 1999:97) menade man att helhetssynen inte bara skall prägla hur man ser på klienten, utan också hur man arbetar och hur man organiserar sig. Dock motsätter man sig inte specialisering, bara detta inte påverkar helhetssynen i arbetet med klienten. Stödet till klienten kan bli mer kompetent och effektivt genom att IFO organiseras i olika funktioner.

Kommunernas frihet att själva välja hur man vill organisera det sociala arbetet (Kommunallagen 3 kap) gör att det i Sverige idag finns ett stort antal olika modeller för hur man organiserar IFO. I en del kommuner är den traditionella IFOverksamheten inte längre samlad under en och samma nämnd, utan barnavårdsfrågor samsas exempelvis med frågor som rör utbildning, och ekonomiskt bistånd återfinns i nämnden för arbetsmarknadsfrågor. På samma gång finns det också kommuner som efter att ha varit organiserade enligt specialiseringsprincipen återgår till en mer integrerad arbetsmodell för att skapa en bättre helhetssyn i arbetet med klienten. De vanligaste organisationsprinciperna inom IFO är integrering och specialisering. Vanliga specialiseringsområden är t.ex. mottagning; ekonomiskt bistånd; barn-, ungdoms- och familjearbete; missbruk; socialjour etc. En del kommuner delar också upp det sociala arbetet i t.ex. utredning och insats eller myndighetsutövning och behandling (Bergmark \& Lundström 1998).

Vid en ytlig betraktelse tycks det organisatoriska landskapet vara ganska splittrat. Men hur ser det egentligen ut?

Syftet med den här artikeln är att beskriva hur individ- och familjeomsorgen i Sveriges kommuner är organiserad med avseende på specialisering och integrering. 
Följande tre frågeställningar bildar utgångspunkt för studien:

- Hur är kommunernas IFO-verksamhet organiserad idag (2008)?

- Finns det något samband mellan kommunstorlek och organisationstyp?

- Hur har kommunernas IFO-organisationer förändrats sedan slutet av 1980talet?

Artikeln inleds med en kortare presentation av tidigare forskning som rör IFOs organisation, därefter redovisar vi hur IFO är organiserad i Sveriges kommuner idag, och avslutningsvis berör vi orsaker till och effekter av det nuvarande organisatoriska läget.

\section{Tidigare forskning}

Den studie som redovisas i den här artikeln ingår i ett större forskningsprojekt om organisering av socialtjänstens IFO. ${ }^{1}$ Inom ramen för projektet genomfördes en omfattande litteratursökning i syfte att kartlägga den befintliga forskningen om individ- och familjeomsorgens organisering både i Sverige och internationellt. De databaser som genomsöktes var: Academic Search Elite (EBSCO), Applied Social Sciences Index (ASSIA), Social services abstract, Sociological abstracts, PAIS, Web of science (SCIexpanded, SSCI, A\&HCI), ERIC, Arbline samt Artikelsök. Följande sökord användes i olika kombinationer: personal social ser-

1 Projektet heter "Specialisering eller integration av socialtjänstens individ- och familjeomsorg? Effekter på insatser och resultat» och finansieras av Forskningsrådet för arbetsliv och socialvetenskap (FAS). vice, organisation, integrated social service, specialised social service, integration, specialisation, social work, generic social work, socialtjänst, organisation, specialisering, generalisering, integrering, socialt arbete, socialsekreterare, specialisering.

Utöver detta har vi särskilt gått igenom svenska doktorsavhandlingar och forskningsrapporter i socialt arbete. Statliga utredningar och direktiv samt Socialstyrelsens rapportserier har också granskats för att hitta litteratur som behandlar området IFOs organisation. Totalt bedömdes 169 publikationer ha viss relevans för forskningsprojektets inriktning. I den här artikeln redovisas främst den del av forskningen som rör specifikt svenska förhållanden.

IFO i Sveriges kommuner har genomgått omfattande förändringar sedan den nya socialtjänstlagen trädde i kraft 1982, men kunskapen om hur omfattande specialiseringen är och hur den tar sig i uttryck är begränsad till ett fåtal studier. På uppdrag av Socialstyrelsen genomförde Bengt Eriksson och Per-Åke Karlsson 1988-1989 en enkätundersökning i alla Sveriges kommuner för att kartlägga kommunernas IFO-organisation. Enkätundersökningen kompletterades med data om kommunernas kostnader för IFO och för socialbidrag, samt uppgifter om antalet socialsekreterare. Dessa data har sedan relaterats till kommunernas invånarantal. Det huvudsakliga syftet med studien var att kartlägga organisationsformer inom IFO i Sverige under en tidsperiod när behovet av specialisering inom IFO var ett hett diskussionsämne. Ett av studiens delsyften var att undersöka i vilken mån debatten om behoven av specialisering avspeglade faktiska organisatoriska förändringar i syfte 
att öka specialiseringen. Vid tidpunkten för studiens genomförande hade 48 procent av kommunerna en integrerad organisationsmodell, och den vanligaste specialiseringstypen var att man hade särskilda ekonomienheter, något som förekom i 51 procent av kommunerna (Eriksson \& Karlsson 1989). Den senaste genomgången av kommunernas IFO-organisationer kommer från Åke Bergmark och Tommy Lundströms IFOprojekt där man bl.a. undersökt hur 100 svenska kommuner med ett invånarantal mellan 13000 och 65000 organiserat det sociala arbetet. 97 procent av kommunerna redovisade någon form av specialisering av ekonomiärenden, 92 procent hade en specialiserad handläggning av barnavårdsärenden, och 90 procent av missbruksärenden. En helt integrerad verksamhet förekommer alltså bara i tre procent av kommunerna $\mathrm{i}$ deras studie (Bergmark \& Lundström 2005). Bergmark och Lundström (2007) fastslår att den entydigt viktigaste organisatoriska trenden inom IFO är den ökade specialiseringen.

I Socialstyrelsens lägesrapport från 2005 (Socialstyrelsen 2006) konstateras att kommunernas IFO-organisationer kan följa lagstiftning, målgrupper, ekonomiska styrprinciper etc. I och med att socialtjänsten har det yttersta ansvaret för kommuninvånarna kan kommunerna tvingas till en viss typ av organisering för att kunna hantera insatser utanför det egna uppdragsområdet för att andra myndigheter, till exempel arbetsförmedling, försäkringskassa samt hälso- och sjukvård inte utför sina arbetsuppgifter enligt uppdrag. Socialstyrelsen pekar på att den generella tendensen är en ökad specialisering inom IFO. Det gäller framförallt inom större kommuner, där det också finns en större risk för bristande kontinuitet och helhetssyn, något som är lättare att upprätthålla i mindre kommuner.

När det gäller organisationens effekter på klientarbetet finns det studier som påvisar såväl positiva som negativa effekter av specialisering. Studier som pekar på positiva effekter är bl.a. Fuller och Tulle-Winton (1996) samt Astvik och Aronsson (1999) som visar på fördelar med en specialisering mot specifika klientgrupper, bl.a. kan utredningar förbättras. En undersökning av Skogens (2001) demonstrerar att socialarbetare i specialiserade organisationer gör striktare bedömningar. Minas (2005) påvisar att specialiserade mottagningsenheter erbjuder personer som söker ekonomiskt bistånd bättre möjligheter att finna alternativa lösningar. I en brittisk undersökning observerar Cambridge och Parkes (2006) ett antal fördelar med särskilda wadult protection co-ordinators", bland annat bättre kunskaper hos socialarbetarna, ökad objektivitet och tydligare åtskillnad mellan utredning och insatser, samt mer fokuserade insatser.

Negativa konsekvenser av specialisering, redovisas bl.a. när det gäller placering av barn i fosterhem (Börjeson \& Håkansson 1990). En specialisering med uppdelning på utredning och insats ledde till att de socialarbetare som arbetade med utredning inte hade tillräckliga kunskaper om samspelet $i$ familjerna för att kunna utföra sitt arbete på ett tillfredsställande sätt. Danermark och Kullberg (1999) pekar på att socialarbetare i specialiserade organisationer tenderar att ha bristfälliga kunskaper om problemens omfattning och karaktär. Söder- 
feldt (1997) visar att specialisering av socialtjänstens arbete kan leda till att socialarbetaren distanserar sig från klienten, och Frogget (1996) att specialisering kan leda till instrumentalisering av handläggningsarbetet. Minas (2005) menar att arbetet i specialiserade mottagningsenheter leder till ökade svårigheter för möjliga klienter att ta sig förbi mottagningsenheten, liknad vid en grindvakt, in i systemet, och att det i sin tur gör att klienter utvecklar olika strategier för att komma in i systemet. Blom (1998) visar att den strikt funktionsuppdelade IFOorganisationen, i många avseenden, misslyckades med att tillfredsställa klienternas behov och önskemål, i synnerhet då problematiken var komplex och sammanflätad. Dessutom medförde specialiseringen en samarbetsproblematik både inom IFO och gentemot andra organisationer.

Den tidigare forskningen om IFOs organisering visar alltså att utvecklingen går mot en allt mer specialiserad organisationsstruktur, samtidigt saknas forskningsresultat som entydigt visar att specialiserade organisationer är den lämpligaste organisationsformen för att socialarbetarna skall kunna utföra sina uppgifter. Möjliga anledningar till den ökade specialiseringen diskuteras i slutet av artikeln.

\section{Olika former av specialisering och integrering}

I det här avsnittet redogör vi för olika former av integrering och specialisering när det gäller IFOs organisation. I litteraturen finns exempel på flera olika definitioner av specialisering inom socialt arbete. I denna studie har vi bland annat utgått från en definition av Doel (1997), som modifierats av Blom (2004) för att bättre passa in på svenska förhållanden. Här finner vi sex olika typer av specialisering av socialt arbete:

1. Fält: sjukhus, skola, kyrka etc.

2. Omgivning: socialkontor, fältarbete, hemma hos

3. Ålder: barn, ungdomar, vuxna, äldre

4. Problem: psykisk hälsa, alkoholmissbruk, ekonomi, relationer

5. Metod: kognitiva metoder, systemteori, case-management, gruppterapi

6. Funktion: mottagning, utredning, behandling/insats, service

I svensk forskningslitteratur används ibland begreppet funktionell specialisering eller funktionsspecialisering för att beteckna den kategori som ovan benämns problem (4), och begreppet uppgiftsspecialisering används för funktionsspecialiseringen (6) (se t.ex. Bergmark \& Lundström 2005, Wiklund 2006). Begreppet funktionsspecialisering används också på olika sätt, både i litteraturen och olika kommuner, men det betyder vanligtvis en speciell enhet som utför en specifik arbetsuppgift, arbetar med en viss grupp etc. I den här studien benämner vi punkt 4 för problemspecialisering och punkt 6 för funktionsspecialisering. Utöver den formaliserade organisatoriska specialiseringen förkommer också att enskilda personer vid en enhet har till uppgift att ansvara för vissa specifika uppgifter, till exempel förhandsbedömningar, uppföljningar eller en viss typ av utredningar, s.k. personbunden specialisering 
(t.ex. Strantz 2007). Sammanfattningsvis finns det alltså olika betydelser av begreppet specialisering av socialt arbete. Det är viktigt att ha det $\mathrm{i}$ åtanke eftersom man ofta talar om olika saker när inte begreppet klart definieras. ${ }^{2}$ Låt oss också peka på några olika betydelser av begreppet integrering.

I Eriksson och Karlssons undersökning från 1989 motsvarar begreppet funktionsorganisation en organisation med en enhetschef som leder en arbetsgrupp där gruppens medlemmar arbetar uteslutande inom IFO. Detta till skillnad från en geografiskt sammanhällen organisation som är en organisation med en enhetschef där gruppens medlemmar arbetar inom ett eller flera av socialtjänstens områden förutom IFO.

De integrerade socialtjänstorganisationerna kan, beroende på kommunens storlek, vara organiserade enligt en geografisk princip för att på så sätt begränsa upptagningsområdet för socialarbetarnas ansvar. En idé bakom den geografiska organisationsprincipen är att man inom socialtjänsten förutom det direkta klientarbetet också ska arbeta förebyggande ute i bostadsområdena, så att man kommer nära sin målgrupp. Detta sätt att organisera IFO var relativt vanligt under 1980-talet. Arbetet organiserades då ofta under sociala distriktsnämnder eller kommundelsnämnder som också hade ansvar för t.ex. utbildningsfrågor på distriktsnivå,

2 Ytterligare ett sätt att se på specialisering erbjuder Mintzberg (1993), som skiljer på vertikal och horisontell specialisering. Bl.a. anser Mintzberg att professionaliserade yrken kännetecknas av en hög horisontell men låg vertikal specialisering. vilket förenklade samarbetet mellan olika myndigheter (Persson 1987).

Här redovisar vi, baserat på kategoriseringar av vårt empiriska material, fem renodlade exempel på hur socialtjänstens IFO kan organiseras i Sverige. För tydlighetens skull vill vi påpeka att respektive modell finns i ett antal varianter runt om i landet.

\section{Figur I.}

Den integrerade socialtjänstorganisationen.

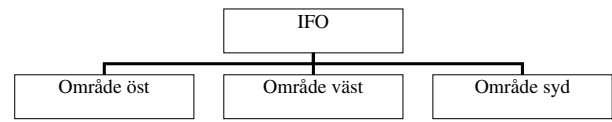

I den här figuren är IFO-verksamheten indelad i geografiska områden. Andra varianter är IFO-områden utifrån stadsdelar eller kommundelar. I varje område bedrivs alla former av IFO-verksamhet. Icke desto mindre kan det förekomma att ett av områdena i en integrerad kommun har ett särskilt ansvar för t.ex. familjejuridiska frågor, och familjerätten är då gemensam för samtliga områden.

\section{Figur 2.}

Organisation med personbunden specialisering

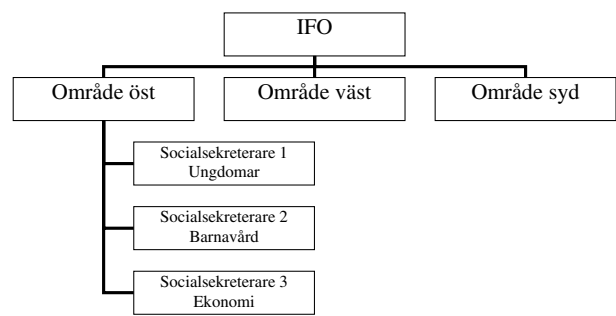

Till skillnad från den förra figuren har socialsekreterarna i en organisation med personbunden specialisering specifika arbetsuppgifter. Man arbetar fortfarande enligt generalistprincip, där alla socialsekreterare arbetar med alla typer av uppgifter, men en 
specialisering finns såtillvida att en viss typ av ärenden styrs till en person med särskilt ansvar för just den ärendetypen.

\section{Figur 3.}

Organisation med problembaserad specialisering.

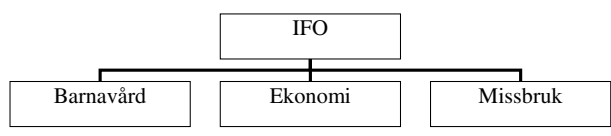

Denna figur visar den vanligaste typen av specialiserad IFO-organisation, där det finns olika enheter som ska matcha olika slags problematik hos klienterna. Specialiseringen kan ibland vara mer långtgående med enheter för t.ex. ungdomsproblematik, psykisk ohälsa, familjeproblematik.

\section{Figur 4.}

Organisation med funktionsbaserad specialisering.

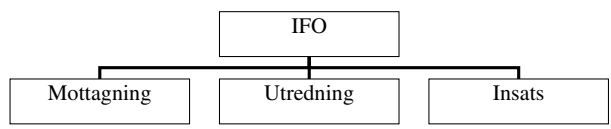

I den här organisationstypen görs en åtskillnad mellan t.ex. utredning och insats. I princip är tanken att man på utredningsenheten sköter den renodlade myndighetsutövningen och att man sedan ger insatsenheten i uppdrag att utföra den beslutade insatsen.

\section{Figur 5.}

Multispecialiserad organisation.

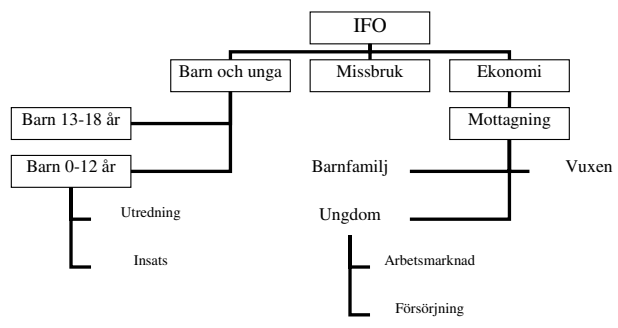

Karaktäristiskt för den multispecialiserade organisationen är att enheterna dels är indelade efter problemtyp, dels efter funktion. Inom enheten för barn och unga finns det en uppdelning efter ålder, men också en mellan utredning och insats. Vidare finns inom ekonomienheten en specialisering mot olika klientgrupper, och inom dessa specialistgrupper finns även en ytterligare uppdelning där man delar in klienterna efter problematik.

De modeller som illustrerats ovan är, som tidigare nämnts, typexempel på hur det kan se ut. Emellertid finns det diverse olika varianter av dessa modeller i landets kommuner. Variationerna handlar om en anpassning till lokala förhållanden och beror delvis på att gränsdragningar mellan olika enheter kan vara svåra att upprätthålla i praktiken. I den här studien har vi fokuserat på problem- och funktionsspecialisering, då de är de vanligast förekommande och också mest framträdande specialiseringsformerna inom IFO i Sveriges kommuner idag.

\section{En tidigare kartläggning av kommunernas IFO- organisationer}

I socialstyrelserapporten Organisationsformer inom socialtjänstens individ- och familjeomsorg (Eriksson \& Karlsson 1989) redovisas en totalundersökning av hur Sveriges kommuners IFO-organisationer var organiserade 1988-89. I undersökningen delades svarsenheterna (kommun eller social distriktsnämnd och eller/kommundelsnämnd) in i sex olika grupper efter storlek på svarsenheterna. 

A. Svarsenhet $<15000$ invånare.
B. 15000-30000 invånare.
C. 30000-50000 invånare.
D. 50000-100000 invånare.
E. 100000-200000 invånare.
F. >200000 invånare.

Vid tidpunkten för undersökningen fanns det 454 svarsenheter av vilka 450 har besvarat enkäten. Innehållet i Tabell 1 nedan liksom i Tabellerna 2, 3 och 4 är hämtat från Eriksson och Karlsson (1989), dock anpassat till vårt syfte. Antal kommuner i Eriksson och Karlssons rapport summerar till 282 vilket är något förvånande eftersom Sverige under åren 1983-91 hade 284 primärkommuner (SCB 2008 s. 29-30).

I Tabell 1 ser vi att bland de minsta kommunerna, med färre än 15000 invånare, var det ingen kommun som hade en geografisk indelning av IFO-organisationen. I övriga kommuner var det så att ju fler invånare en kommun hade, desto större var andelen som hade en geografisk indelning i t.ex. kommundelar, där IFO-verksamheten utfördes.

I Eriksson och Karlssons rapport görs en separat redovisning av antalet särskilda ekonomigrupper, dvs. där ekonomihandläggningen separerats från övrig handläggning (se Tabell 2). 51 procent, dvs. 230, av de 450 svarsenheterna hade en sådan ekonomigrupp. På 1980-talet hade diskussionen om specialisering framförallt fått ett genomslag vad gäller särskiljandet av ekonomigrupper inom IFO, och detta inom loppet av bara ett fåtal år.

Av Tabell 2 framgår att det framförallt är i de större kommunerna som ekonomihandläggningen särskiljts från övrig IFOverksamhet. Dessutom kunde IFO-organisationen se olika ut i de olika kommundelarna inom samma kommun. 91 procent av svarsenheterna i storstäderna hade 1989 en särskild ekonomigrupp.

Många kommuner som i slutet av 1980-

\section{Tabell I.}

Kommuner ( $n=282)$ och svarsenheter ${ }^{*}(n=450)$.

\begin{tabular}{|l|c|c|c|c|c|c|}
\hline Kommunstorlek & A & B & C & D & E & F \\
\hline Antal kommuner & 136 & 73 & 35 & 27 & 8 & 3 \\
\hline Antal svarsenheter per kommun & 1,0 & 1,10 & 1,93 & 3,0 & 7,0 & 11,1 \\
\hline
\end{tabular}

* Tabell 1-4 är hämtade ur Eriksson och Karlsson (1989).

\section{Tabell 2.}

Särskilda ekonomigrupper i slutet av 1980-talet ( $n=230$ ). Fördelning efter svarsenhetens storlek.

\begin{tabular}{|l|c|c|c|c|c|c|c|}
\hline & Samtliga & A & B & C & D & E & F \\
\hline Procent & 51 & 28 & 56 & 66 & 65 & 43 & 91 \\
\hline Absoluta tal & 230 & 39 & 43 & 41 & 51 & 24 & 32 \\
\hline
\end{tabular}


talet hade särskilda grupper för handläggning av ekonomiärenden hade också specialiserade grupper med inriktning på olika klientgrupper, t.ex. barn och familj, ungdom, vuxen etc. I Eriksson och Karlssons undersökning gavs kommunerna möjlighet att svara på frågan om det i IFOorganisationen fanns särskilda grupper för arbete med barn och familjer, ungdomar, eller vuxna. Det var därmed möjligt att ange förekomst av flera olika arbetsgrupper (i Eriksson \& Karlsson kallade behandlingsgrupper) och samtidigt ange förekomst av icke-differentierad arbetsgrupp, till exempel att det förekom en specialiserad grupp på missbruksområdet, men inte på barnavårdsområdet. Därför är antalet svar i Tabell 3 fler än antalet svarsenheter.
Tabell 3 visar att en särskild grupp för arbete med vuxna - näst särskilda ekonomigrupper (se Tabell 2) - var den vanligast förekommande specialiserade gruppen i Eriksson och Karlssons undersökning. Ett stort bortfall gör att det inte är möjligt att utifrån svaret på denna fråga dra några slutsatser om samband mellan kommunstorlek och avsaknad av differentierade grupper. Däremot är det värt att notera att den icke-differentierade organisationstypen även förekommer i stor utsträckning i kommuner med större invånarantal.

I närmare hälften av fallen i Eriksson och Karlssons undersökning (se Tabell 4) är svarsenheterna icke specialiserade, dvs. ingen uppdelning är gjord i olika enheter som har olika ansvarsområden och arbets-

\section{Tabell 3.}

Differentierade arbetsgrupper vid slutet av 1980-talet (n=677). Fördelning efter svarsenhetens storlek.

\begin{tabular}{|l|c|c|c|c|c|c|c|}
\hline & \multicolumn{6}{|l|}{ Samtliga (procent/absoluta tal) } \\
\hline & Totalt & A & B & C & D & E & F \\
\hline Ej diff. & $38 / 172$ & $33 / 46$ & $55 / 42$ & $56 / 35$ & $26 / 20$ & $36 / 20$ & $23 / 8$ \\
BoF** $^{*}$ & $25 / 113$ & $7 / 10$ & $22 / 17$ & $16 / 10$ & $49 / 38$ & $25 / 14$ & $69 / 24$ \\
Ungdom & $22 / 98$ & $6 / 8$ & $19 / 15$ & $21 / 13$ & $41 / 32$ & $20 / 11$ & $54 / 19$ \\
Vuxen & $29 / 129$ & $11 / 15$ & $21 / 16$ & $26 / 16$ & $55 / 43$ & $27 / 15$ & $66 / 23$ \\
Ingen uppgift & $37 / 165$ & $57 / 78$ & $23 / 18$ & $27 / 17$ & $29 / 23$ & $43 / 24$ & $11 / 4$ \\
\hline
\end{tabular}

** BoF står för Barn- och familjegrupp.

\section{Tabell 4.}

Icke specialiserade organisationer vid slutet av 1980-talet ( $n=215)$. Fördelning efter svarsenhetens storlek.

\begin{tabular}{|l|c|c|c|c|c|c|c|}
\hline & Samtliga & A & B & C & D & E & F \\
\hline Procent & 48 & 71 & 42 & 37 & 26 & 61 & 20 \\
\hline Absoluta tal & 215 & 98 & 32 & 23 & 20 & 34 & 7 \\
\hline
\end{tabular}


uppgifter. Framförallt är det de mindre kommunerna som har en icke-specialiserad organisation, där socialsekreterarna arbetar som generalister. I dessa kommuner kan det emellertid förekomma att enskilda personer har specifika arbetsuppgifter, alltså en sorts personbunden specialisering.

Sammanfattningsvis kan vi alltså se att i slutet på 1980-talet fanns tendenser till en hög grad av specialisering, särskilt inom området ekonomiskt bistånd. Den integrerade organisationen hade emellertid fortfarande en stark ställning. Hur ser det då ut ungefär tjugo år senare?

\section{Svenska IFO-organisationer 2005-2008}

I det här avsnittet redovisar vi vår undersökning av svenska kommuners IFO-organisationer som genomfördes under perioden 2005 till 2008.

\section{Tillvägagångssätt}

Sveriges samtliga 290 kommuner ingår i undersökningen. Kommunernas IFOorganisationer har i första hand studerats via de kommunala informationssidorna på Internet, där många kommuner publicerat tämligen utförlig information om socialtjänstens organisation.

Att samla in data via kommunernas hemsidor innebär en viss osäkerhet rörande materialets reliabilitet och validitet. Det kan finnas variation kommunerna emellan med avseende på vad man väljer att redo- visa när det gäller organisationsmodellernas beståndsdelar, samt vad man lägger för betydelse i de olika begrepp som används för att beskriva organisationerna. Det kan även vara så att information som utåt sett förefaller stämma kan vara missledande; bakom likartade beskrivningar i två olika kommuner kan det dölja sig delvis olikartade praktiker. Samtidigt är det rimligt att anta att många kommuner har tämligen uttömmande och tillförlitlig information på sina hemsidor. Till exempel vet vi att informationen på hemsidorna är korrekt när det gäller de tre IFO-organisationer som vi detaljstuderat inom ramen för forskningsprojektet. Dessutom, i slutet av artikeln pekar vi på att resultaten visar stor överensstämmelse med en studie som undersökt IFOs organisering via enkätdata (Bergmark \& Lundström 2005). Det innebär en, indirekt, metodtriangulering som indikerar att materialet på hemsidorna är relativt tillförlitligt.

Vi har försökt hantera problematiken med materialets validitet och reliabilitet genom att kontakta de kommuner där informationen varit otydlig eller där en beskrivning av socialtjänstens organisation har saknats. Det har i första hand skett via e-post och i andra hand via telefon. I de fall kommunen kontaktats via e-post eller telefon har frågor ställts om IFO-organisationen, om eventuella enheter/grupper, om socialsekreterarna har specifika arbetsuppgifter eller arbetar enligt generalistmodell.

Många kommuner har då lämnat en tämligen omfattande beskrivning av hur man organiserat arbetet inom IFO. Det primära syftet har inte varit att ta reda på vilka enheter (t.ex. barnavård eller ekonomi) som 
finns i kommunernas IFO-organisationer, utan att ta reda på vilken typ av organisation man har utifrån de olika formerna av specialisering och integrering. I de kommuner där socialtjänstverksamheten är uppdelad i mindre geografiska självstyrande distrikt eller stadsdelar, t.ex. storstäderna och en del av övriga större städer är de organisatoriska principerna i samtliga fall i stort sett identiska, även om de yttrar sig på delvis olika sätt. Man kan i dessa distrikt till exempel ha enheter baserade på en problembaserad specialisering, men vilka enheter (problemgrupper) man arbetar med kan variera mellan distrikten/stadsdelarna. Detta har dock inte undersökts i vår studie. Datainsamlingen genomfördes under åren 2005 till 2008. Större delen av insamlingen skedde under 2006.

Vid kategorisering av undersökningskommunerna har den senaste versionen av Sveriges kommuner och landstings kommungruppsindelning använts (http://www. skl.se/artikel.asp?A=11248\&C=445). I den nya kommungruppsindelningen från 2005 har man tagit hänsyn till strukturella egenskaper som befolkningsstorlek, pendlingsmönster och näringslivsstruktur.

I den aktuella kommungruppsindelningen finns följande kategorier:

\section{Storstäder (3 kommuner)}

2. Förortskommuner (38 kommuner)

3. Större städer (27 kommuner)

4. Pendlingskommuner (41 kommuner)

5. Glesbygdskommuner (39 kommuner)

6. Varuproducerande kommuner (40 kommuner)

7. Övriga kommuner, över 25000 inv. (33 kommuner)
8. Övriga kommuner, 12 500-25 000 inv.

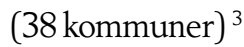

9. Övriga kommuner, mindre än 12500 inv. (31 kommuner)

Nedan presenteras resultatet av undersökningen där vi redovisar hur många av kommunerna som har en organisation med funktions-, problem- eller multispecialisering. Övriga förekommande typer av specialisering (se avsnittet om specialisering), har inte specifikt undersökts i den här studien.

\section{Funktionsspecialisering}

I kommuner där IFO är organiserad enligt en funktionsprincip kan socialsekreterarnas arbetsuppgifter antingen bestå av t.ex. utredningsarbete eller insatsarbete. I en kommun som också har en problemspecialisering (multispecialiserad organisation, se Tabell 7) kan arbetet vara inriktad på utredning eller insats i en viss (problembaserad) grupp.

I Tabell 5 har vi operationellt definierat kommuner med blandformer enligt det följande. En integrerad organisation med drag av funktionsspecialisering (kategori 2) avser en kommun där nästan samtliga socialarbetare arbetar med i princip alla typer av ären-

3 Sedan undersökningen inleddes har antalet kommuner i kategori 7 och 8 förändrats så tillvida att en kommun från kategori 8 utökat sitt invånarantal och befinner sig numer i kategori 7. I den här studien utgår vi från den version av kommungruppsindelningen som var gällande 2006. 
den, men där det t.ex. kan finnas en viss styrning av utredningar eller insatser mot särskilda socialsekreterare (t.ex. vid utredning i samband med klienters dödsfall). I en funktionsspecialiserad organisation med drag av integrering (kategori 3), sker det motsatta. Där kan man t.ex. i en särskild utredningsenhet ibland göra vissa insatser (stödsamtal, ekonomiskt bistånd m.m.), trots att det finns en eller flera insatsenheter som sedan skall ta över ärendet.

Av Tabell 5 framgår att ungefär 15 procent av kommunerna har en organisation där socialarbetarna är uppdelade i olika grupper utefter vilken typ av uppgift de utför. Den här typen av organisation förekommer oftast i kommuner med en hög grad av specialisering, i kombination med en problembaserad gruppindelning. Den här typen av organisering förekommer i samtliga storstäder samt i 15 (56 procent) av de större städerna. Den är mindre vanlig i de små kommunerna. Det är intressant att notera att en del av förortskommunerna har ett invånarantal som liknar, eller i flera fall är större än de större städerna, men i förortskommunerna är det mindre vanligt med funktionsspecialiserade IFO-organisationer. Det finns alltså inget entydigt samband mellan kommunstorlek och funktionsspecialisering. Det som dock framstår tydligast är att de allra flesta kommunerna i Sverige, 242 kommuner eller 83 procent, inte har en funktionsspecialiserad IFO-organisation.

\section{Problemspecialisering}

I en organisation som är specialiserad mot olika problemområden arbetar socialse-

\section{Tabell 5.}

Funktionsspecialisering ( $N=290)$.

$0=$ ingen funktionsspecialisering, $1=$ funktionsspecialisering, $2=$ integrerad organisation med drag av funktionsspecialisering, $3=$ funktionsspecialiserad organisation med drag av integrering.

\begin{tabular}{|c|c|c|c|c|c|}
\hline \multirow[b]{2}{*}{ Kommuntyp } & \multicolumn{5}{|c|}{ Funktionsspecialisering } \\
\hline & 0 & । & 2 & 3 & Totalt \\
\hline Storstad & & 3 & & & 3 \\
\hline Förortskommun & 33 & 5 & & & 38 \\
\hline Större städer & 12 & 15 & & & 27 \\
\hline Pendlingskommun & 38 & 2 & । & & 41 \\
\hline Glesbygdskommun & 36 & 2 & । & & 39 \\
\hline Varuproducerande kommun & 36 & 4 & & & 40 \\
\hline Övrig kommun >25 000 & 25 & 6 & । & । & 33 \\
\hline Övrig kommun I 2500-25000 & 32 & 5 & । & & 38 \\
\hline Övrig kommun <12500 & 30 & I & & & 31 \\
\hline Totalt & 242 & 43 & 4 & I & 290 \\
\hline
\end{tabular}

Lundgren, Blom, Morén \& Perlinski: Från integrering till specialisering... 
kreterarna i arbetsgrupper där man möter klientgrupper med en viss typ av problematik, t.ex. missbruk, ekonomiska svårigheter, barn som far illa etc. Det är den vanligaste formen av specialisering, och den återfinns i 256 av kommunerna, närmare 90 procent, att jämföra med 52 procent 1989 (Eriksson \& Karlsson 1989).

En ofta förekommande gruppindelning som motsvarar de gamla socialvårdslagarna är: barngrupp, ekonomigrupp och missbruksgrupp. Detta är en organisationstyp som är utsatt för förändringar när "nya» klientgrupper identifieras, t.ex. finns det i en del kommuners IFO-organisationer en särskild arbetsgrupp för frågor som rör unga vuxna eller integration av flyktingar (Bergmark \& Lundström 2005, Skogens 2001).

I Tabell 6 har vi operationellt definierat kommuner i kategorierna 2 och 3 (blandformerna) på följande vis. En integrerad organisation med drag av problemspecialisering (kategori 2) är en kommun där i princip alla socialarbetare arbetar med nästan all slags problematik, men där det kan ske en styrning av en viss typ av problem (t.ex. spelmissbruk) mot särskilda socialsekreterare. I en organisation som har problemspecialisering med drag av integrering (kategori 3) kan en enhet ibland arbeta med flera olika typer av problem, trots att organisationen har särskilda enheter med uppgift att hantera olika problem. Det kan t.ex. innebära att en enhet för barnavårdsutredningar även handlägger ekonomiärenden under utredningstiden, trots att organisationen har en särskild ekonomienhet.

Tabell 6 visar att 24 kommuner, eller 8 procent, av kommunerna inte har problembaserad specialisering av IFO. Flertalet av dessa kommuner har ett lågt invånarantal. Däremot har samtliga större kommuner någon form av problemspecialiserad organisation.

\section{Tabell 6.}

Problemspecialisering $(\mathrm{N}=290)$.

$0=$ ingen problemspecialisering, $1=$ problemspecialisering, 2=integrerad organisation med drag av problemspecialisering, $3=$ problemspecialisering med drag av integrering.

\begin{tabular}{|c|c|c|c|c|c|}
\hline \multicolumn{6}{|c|}{ Problemspecialisering } \\
\hline Kommuntyp & 0 & 1 & 2 & 3 & Totalt \\
\hline Storstad & & 3 & & & 3 \\
\hline Förortskommun & & 36 & । & । & 38 \\
\hline Större städer & & 27 & & & 27 \\
\hline Pendlingskommun & । & 39 & I & & 41 \\
\hline Glesbygdskommun & 18 & 19 & I & । & 39 \\
\hline Varuproducerande kommun & 3 & 35 & 2 & & 40 \\
\hline Övrig kommun >25000 & & 32 & & । & 33 \\
\hline Övrig kommun I2 500-25000 & I & 37 & & & 38 \\
\hline Övrig kommun $<12000$ & । & 29 & । & & 31 \\
\hline Totalt & 24 & 256 & 6 & 3 & 290 \\
\hline
\end{tabular}




\section{Multispecialiserade organisationer}

De multispecialiserade organisationerna är både problem- och funktionsspecialiserade. Det kan dessutom förekomma t.ex. intern specialisering, dvs. att det inom den redan specialiserade enheten finns grupper eller personer som arbetar med specifika arbetsuppgifter. I Tabell 7 beskrivs kommunerna samtidigt utifrån variablerna funktionsindelning och problemspecialisering. Det framgår av tabellen att samtliga storstäder är både funktions- och problemspecialiserade. Totalt är ca 16 procent, 45 kommuner, både problem-och funktionsspecialiserade. De har en IFO-organisation där socialarbetarna dels är indelade efter klientgruppens problematik, dels efter vilken sorts arbete man utför, till exempel utrednings- eller behandlingsarbete. De flesta kommuner är dock endast problemspecialiserade.

Vi ser att det i dagsläget är 7 procent av kommunerna som arbetar integrerat, en arbetsmodell som är vanligast i glesbygdskommunerna.

1989 var 48 procent av kommunernas IFO-verksamheter organiserade enligt generalistmodellen (Eriksson \& Karlsson 1989). I Bergmark och Lundströms undersökning från 2005 var det endast 3 procent av kommunerna som hade en liknande indelning, men då omfattade undersökningen inte kommuner med färre än 13000 invånare (Bergmark \& Lundström 2005). Man kan alltså konstatera att det skett en ökad specialisering av kommunernas IFOorganisationer mellan 1989 och 2008. De multispecialiserade organisationerna utgör idag närmare 16 procent.

Även om vi i vår studie inte använt samma undersökningsenheter som Eriksson och Karlsson (dvs. både kommuner och kommundelar), och den äldre undersökningen därför omfattar fler undersökningsenheter ( $\mathrm{N}=454$ jämfört med $\mathrm{N}=290$ ), kan vi tydligt se att specialiseringen ökat sedan 1989. Då hade 51 procent av kommu-

\section{Tabell 7.}

Multispecialiserade organisationer $(\mathrm{N}=290)$.

\begin{tabular}{|l|c|c|c|c|c|}
\hline & \multicolumn{2}{|c|}{ Ingen funktionsindelning } & \multicolumn{2}{|c|}{ Funktionsindelning } & Totalt \\
\hline Kommuntyp & Ej Problem & Problem & Ej problem & Problem & \\
\hline Storstad & & & & 3 & $\mathbf{3}$ \\
Förortskommun & & 33 & & 5 & $\mathbf{3 8}$ \\
Större städer & & $\mid 2$ & & 15 & $\mathbf{2 7}$ \\
Pendlingskommun & $\mid$ & 37 & & 3 & $\mathbf{4 I}$ \\
Glesbygdskommun & $\mid 7$ & $\mid 9$ & $\mid$ & 2 & $\mathbf{3 9}$ \\
Varuproducerande kommun & $\mid$ & 35 & 2 & 2 & $\mathbf{4 0}$ \\
Övrig kommun $>25000$ & & 25 & & 8 & $\mathbf{3 3}$ \\
Övrig kommun I2500-25000 & $\mid$ & $3 \mid$ & & 6 & $\mathbf{3 8}$ \\
Övrig kommun <12500 & $\mid$ & 29 & & 1 & $\mathbf{3 I}$ \\
\hline Totalt & $\mathbf{2 0}$ & $\mathbf{2 2 2}$ & $\mathbf{3}$ & $\mathbf{4 5}$ & $\mathbf{2 9 0}$ \\
\hline
\end{tabular}

Lundgren, Blom, Morén \& Perlinski: Från integrering till specialisering.. 
nerna en särskild grupp för handläggning av ekonomiärenden, vilket var den vanligast förekommande specialiseringen vid den tidpunkten. Då det i denna undersökning inte varit aktuellt att undersöka vilka differentierade grupper som förekommer i kommunernas problemindelning får vi istället jämföra resultatet från 1989 med de 88 procent av kommunerna som idag har en problemspecialisering.

Figur 6 är ett försök att illustrera var IFO-organisationerna för närvarande befinner sig på en organisatorisk karta bestående av dimensionerna problemspecialisering och funktionsspecialisering.

Figuren illustrerar att de allra flesta IFO-organisationer har en problembaserad specialisering, även om det finns tendenser till att delvis arbeta integrerat och delvis arbeta funktionsspecialiserat i dessa kommuner. Ett fåtal kommuner, de flesta med ett lägre invånarantal, arbetar integrerat. Att arbeta specialiserat både med avseende på problem och funktion är vanligast i landets till invånarantalet större kommuner.

\section{Förändring och specialisering av socialtjänstorganisationer}

Vilka skäl finns till den förändring av kommunernas IFO-organisationer som skett sedan 1989? Socialtjänstlagen, med helhetssynen som ledstjärna, har inte förändrats nämnvärt, åtminstone inte med avseende på hur socialtjänstens organisation skall utformas.

Den tilltagande specialiseringen av soci-

\section{Figur 6.}

Organisatorisk karta över svenska IFO-organisationer 2005-2008.

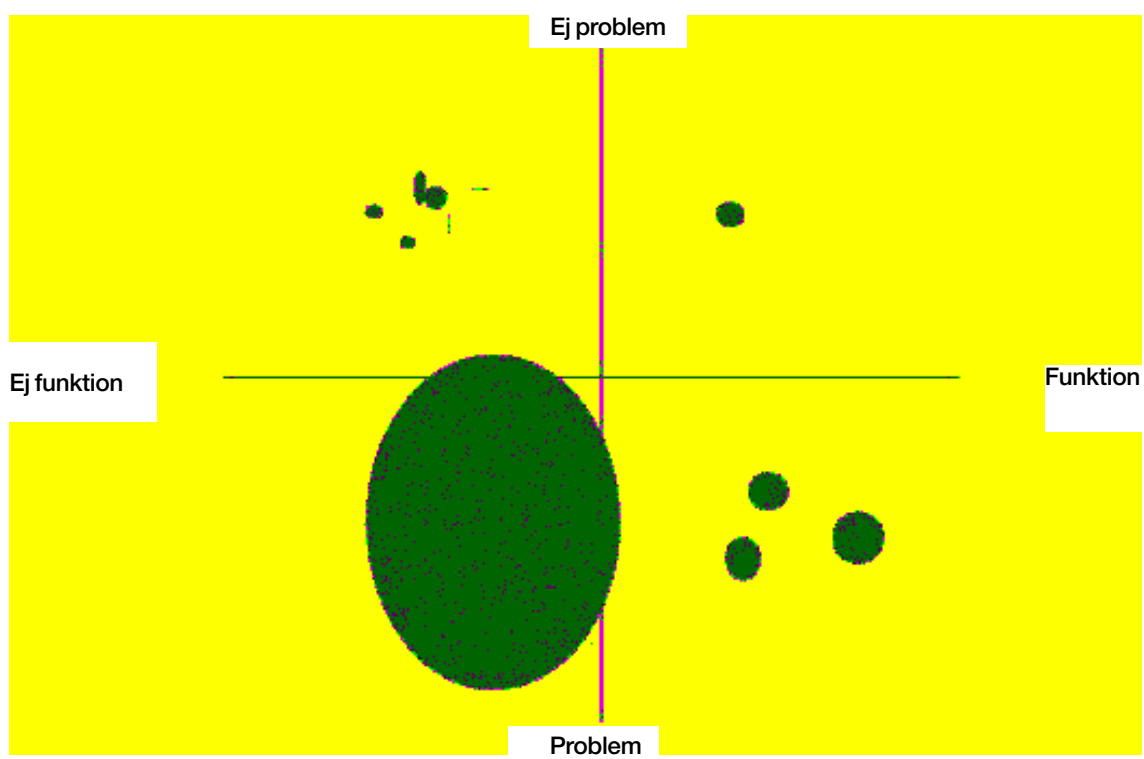


altjänstens IFO kan inte förstås isolerat från faktorer i omvärlden, utan måste sättas in $\mathrm{i}$ ett sammanhang där organisationer successivt förändras som ett svar på behov och förväntningar från samhället (Bergmark \& Lundström 2005, Eriksson \& Karlsson 1989, Skogens 2001). Möjliga anledningar till att socialtjänstens organisation förändras kan bland annat vara:

- Politiska förändringar

- Ändrade ekonomiska förutsättningar

- Professionella strävanden och anspråk

- Förändrad efterfrågan

- "Nyuppkomna« sociala problem

- Isomorfism

Nedan kommenterar vi dessa möjliga anledningar till den ökade specialiseringen inom kommunernas IFO-organisationer.

\section{Politiska förändringar}

Under 1970- och 80-talen fanns en politisk strävan att utöka demokratin och göra medborgarna mer delaktiga i politiska beslut, och det påverkade även kommunernas socialtjänstorganisationer. Genom sociala distriktsnämnder eller kommundelsnämnder och geografiskt indelade (och generalistpräglade) IFO-organisationer skulle brukarinflytandet inom socialtjänsten öka och det sociala arbetet föras närmare sina avnämare (Eriksson \& Karlsson 1989).

Vi kan även se att handläggning av ekonomiskt bistånd är en av de verksamheter inom socialtjänsten som idag är mest specialiserad. Redan i slutet av 1970-talet skiljdes ekonomiskt bistånd ut från övrig
IFO-verksamhet i samband med försöksverksamheten med s.k. SOFT-handläggning (förenklad handläggning). Trots att SOFTförslaget inte genomfördes i sin helhet fick det betydelse för socialtjänstens organisering då det till viss del ligger till grund för den specialiserade, och ofta förenklade, form av handläggning av ekonomiskt bistånd som finns i ett stort antal av landets kommuner (Stranz 2007).

Man kan även konstatera att kommunernas ökade möjligheter att själva besluta över förvaltningsorganisationen gjort att olikheten mellan organisationerna har ökat (Bergmark 2001). Dessutom har ändringar i kommunallagen bidragit till introduktion av olika modeller för marknadslösningar som påverkat utvecklingen av de s.k. beställar-utförarorganisationerna. Det har många gånger medfört en funktionsindelning mellan utredande/beställande respektive utförande enheter inom IFO (Bergmark \& Lundström 2005, Blom 1998).

\section{Ändrade ekonomiska förutsättningar}

En annan anledning till att socialtjänstens organisation förändras kan höra samman med konjunkturförändringar. Exempelvis drar Skogens (2001) paralleller mellan variationer i den ekonomiska konjunkturen och förändring av IFOs organisering. När fler människor i början av 1990-talet blev arbetslösa och i behov av ekonomiskt bistånd skedde samtidigt en specialisering av enheter för ekonomiskt bistånd, då många nytillkomna biståndssökande $\mathrm{i}$ mindre utsträckning hade behov av andra 
sociala insatser. Tanken var att det skulle leda till en effektivare organisation, där handläggarna inom enheten inte behövde arbeta med andra sociala frågor. I en motsvarande högkonjunktur skulle andelen klienter i behov av mer omfattande insatser än ekonomiskt bistånd öka, och kommunerna skulle då kunna gå tillbaka till en mer integrerad organisation (Skogens 2001). Någon sådan konjunkturrelaterad utveckling mot mer generaliserade organisationer har vi inte kunnat urskilja vare sig $i$ vår eller andras undersökningar. Emellertid har vi funnit exempel på att man i ekonomiskt kärva perioder, med ökat behov av effektivisering av socialtjänstens arbete, i några kommuner har gått mot en organisation med ett mer integrerat arbetssätt. Bland annat $i$ en medelstor kommun där man tidigare arbetat problemspecialiserat, med fokus på bl.a. missbruk och ekonomi, har man infört en funktionsindelad organisation med en uppdelning mellan utredning och insats i syfte att förbättra helhetssynen på klientens problematik.

Dessutom har kommunernas ansträngda ekonomi i kombination med mediala drev mot t.ex. bristfälliga barnavårdsutredningar gjort argumentet om att ökad specialisering ger ökad kompetens och i längden ökad effektivitet gångbart (Bergmark \& Lundström 2005).

Många kommuner har också infört en särskild mottagning av nya klienter, organiserad antingen i specifika funktioner, eller genom personbunden specialisering, där ett fåtal personer har till uppdrag att ta emot nya klienter. Genom specialiserade mottagningsenheter vill man snabbare lotsa de sökande vidare till andra lösningar (t.ex. försäkringskassa eller arbetsförmedling), och med hjälp av förhandsbedömningar sortera ut klienter ur systemet utan att mer omfattande utredningar behöver genomföras. En studie av Minas (2005) visar att den här typen av organisatoriska enheter för mottagning kan leda till högre kostnadseffektivitet i organisationen då människor som inte är berättigade till bistånd tidigare sorteras ut från systemet.

\section{Professionella strävanden och anspråk}

Socionomutbildningen i Sverige, och övriga västvärlden, är i huvudsak inriktad mot generalistkompetens (Blom 2004, Wolk \& Wertheimer 1999) trots att tendensen i kommunerna är en ökad specialisering och differentiering. Den här diskrepansen kan till viss del handla om socionomprofessionens strävan att avgränsa sitt arbetsområde och öka sin status i förhållande till andra yrkesgrupper. Här är bland annat strävan efter legitimation ett led i arbetet, vilket kan leda till ökad specialisering, då man därigenom kan hävda ökade specialistkunskaper (Wingfors 2004). Att organisera IFO i specifika enheter, delvis i syfte att uppnå högre kompetens inom respektive problemområde kan även ses som ett steg $i$ arbetet att hävda professionens makt och status i relation till det omgivande samhället (Stranz 2007).

\section{Förändrad efterfrågan}

Ökad massmedial bevakning och ett ökat 
antal anmälningar om barn som far illa har lett till att kraven på socialtjänstens barnavårdsarbete ökat (Bergmark \& Lundström 2005). Det särskilda fokus som en viss målgrupp får kan leda till ökad specialisering i strävan att förbättra kvaliteten i det sociala arbete som riktas mot den målgruppen. Andra exempel än barnavårdsarbete är t.ex. särskilda arbetsmarknadsinriktade enheter för unga och enheter för ungdomsarbete med särskilt fokus på missbruksproblematik.

Därutöver kan konjunkturförändringar - med ett ökat behov av ekonomiskt bistånd när det övriga socialförsäkringssystemet inte räcker till - också leda till en specialisering av särskilda ekonomienheter. Framförallt då många människor som ansöker om ekonomiskt bistånd inte är i behov av övrigt stöd från socialtjänsten (Skogens 2001).

\section{Nyuppkomna sociala problem}

Det som sker i omvärlden påverkar också socialtjänstens organisation genom att nya målgrupper för socialtjänstens arbete uppkommer. Ett exempel på detta är t.ex. kommunernas ansvar för boende för ensamkommande asylsökande barn (Lagen om mottagande av asylsökande m.fl. §§2-3, Socialtjänstlagen 2 kap 2§) . Även om Migrationsverket fortsättningsvis har ett övergripande ansvar för barnen, är det kommunernas ansvar att barnen får boende, men också den eventuella hjälp och stöd som barnen har möjlighet att erhålla genom socialtjänstlagen. Kommunernas nya ansvar kan innebära att man t.ex. inför en person- bunden specialisering, där socialsekreterare inom en viss enhet får till ansvar att arbeta med ensamkommande asylsökande barn, eller en problemspecialiserad indelning, där socialsekreterare som uteslutande arbetar med målgruppen organiseras inom en egen enhet. Exempelvis i Östersunds kommun har man inrättat en särskild enhet där mottagandet av ensamkommande asylsökande barn är organiserat.

\section{Isomorfism}

Sedan slutet av 1980-talet har antalet kommuner med specialiserad IFO ökat från 51 till 93 procent, och framförallt är det problemspecialisering som införts. Det är möjligt att betrakta den organisatoriska likriktningen som ett utslag av det som inom nyinstutionell teori benämns isomorfism (DiMaggio \& Powell 1991). Genom att efterlikna andra organisationer och anamma institutionaliserade handlingsmönster försöker organisationer öka sin legitimitet och effektivitet (Meyer \& Rowan 1991). Framförallt när det saknas vetenskapligt belagda framgångsrika modeller kan det leda till att organisationer tenderar att imitera andra organisationer inom samma verksamhetsområde (DiMaggio \& Powell 1991). Införandet av särskilda dokumentationssystem och arbetssätt inom socialtjänsten kan också leda till att individ- och familjeomsorgens organisation förändras. Ett exempel är införandet av BBIC (Barns Behov i Centrum) där kommuner för att erhålla licens att arbeta med BBIC måste uppfylla ett antal kvalitetskriterier och därmed justerar sin organisa- 
tion för att bättre kunna arbeta enligt BBIC, till exempel genom specialiserade barnavårdsgrupper. Att organisationen förändras som en följd av nya direktiv eller lagstiftning kan ses som ett inslag av s.k. tvingande isomorfism (DiMaggio \& Powell 1991).

\section{En entydig utveckling med oklara effekter}

Vår undersökning visar att under de senaste två decennierna har specialisering av IFO tilltagit och någon form av specialisering är numer den vanligaste organisationsformen. Den övervägande delen av organisationerna är specialiserade enligt problemprincipen, dvs. det finns olika enheter för olika typer av problem, medan funktionsspecialisering är något mindre vanlig. Det förekommer också kommuner som är specialiserade både till funktion och problem, s.k. multispecialisering, men dessa är relativt få och modellen är tydligt relaterad till invånarantal. Här hittar vi de tre storstäderna och ett antal andra större städer. Ett fåtal kommuner, mindre till storleken, har en generalistorganisation. Våra resultat både förstärker och nyanserar tidigare forskning på området. I jämförelse med Bergmark och Lundströms (2005) undersökning där 3 procent av kommunerna arbetade integrerat, framkommer i denna studie att så många som 7 procent av kommunerna är organiserade enligt generalistmodell. Skillnaden kan delvis förklaras av att den förra undersökningen inte innefattade de minsta kommunerna, medan vår studie är en totalundersökning.

Vi ser alltså en tydlig utveckling mot olika typer av specialisering, samtidigt som vi kan notera att forskningen om framgångsrika organisationsmodeller är allt annat än entydig, dvs. det finns inga vetenskaliga belägg för att specialisering är det bästa sättet att organisera IFO på. Motiven bakom kommunernas val av organisatoriska principer är därmed mycket diffusa. Man kan dessutom konstatera att effekterna av IFOs specialisering är oklara.

Ett ofta anfört skäl till att IFO specialiseras är att färre arbetsuppgifter leder till att kompetensen inom ett specifikt område ökar och att klienterna därigenom kan få en kvalitativt bättre hjälp (Bergmark \& Lundström 2005). Men för individer och familjer med mångfacetterad problematik kan det samtidigt innebära att man måste ha kontakt med ett flertal olika socialarbetare inom en organisation, för att få hjälp med hela sin problemsituation. Det innebär också att klientens problem tenderar att definieras och kategoriseras efter hur IFOorganisationen ser ut - i stället för omvänt. Kvaliteten på den service socialtjänsten erbjuder torde rimligtvis påverkas av att det är fler socialsekreterare som klienten skall skapa relation till (Boklund 1995, Howe 1987). Det finns risk för att människor »trillar mellan stolarna» när deras problembild inte stämmer överens med de problemområden som styr IFOs organisering.

Den ökade specialiseringens oklara effekter i klientarbetet kräver vidare forskning om grunderna för IFOs organisering. Man kan bl.a. behöva granska det ofta anförda antagandet att en specialiserad organisationsform leder till ökad kompetens hos socialarbetarna. Det är dessutom viktigt att göra en åtskillnad mellan specialiserad 
organisation och specialiserad kompetens. Fördjupad kompetens hos enskilda socialarbetare behöver inte vara liktydigt med specialisering och kan sannolikt uppnås på flera olika sätt - och även i en integrerad organisation. En annan problematik kopplad till specialisering är behovet av ökad samverkan. I det forskningsprojekt som denna studie ingår i har vi intervjuat socialarbetare såväl som socialnämndspolitiker och högre socialtjänstemän i tre svenska kommuner med olika typer av IFO-organisationer. I intervjuerna framkommer att ett av de stora problemen med den specialiserade socialtjänstorganisationen är att det finns stora brister i samverkan mellan de olika enheterna inom organisationen (Morén et al. kommande, Perlinski et al. kommande). Den förväntade effektiviseringen kan alltså vändas till ineffektivitet, då bristfällig sam- verkan kan leda till motstridiga beslut. Det kan handla om vårdplaner som strider mot varandra när klienten har kontakt med olika enheter och ingen samverkan sker mellan enheterna eller att socialarbetarnas kunskaper om klienterna brister då man inte arbetar med hela problembilden (Blom 2004, Danermark \& Kullberg 1999).

Frågan om hur IFO bör organiseras är knappast slutgiltigt besvarad, även om det vid en titt på det organisatoriska landskapet kan förefalla som att problemspecialisering utkristalliserats som den bästa organisationsprincipen. Exakt hur IFO bör organiseras framgent är svårt att säga, men vi menar att det är rimligt att utgå ifrån behovet av både bredd och djup i kompetensen hos enskilda socialarbetare och att därefter fråga vilka krav som det ställer på organisationsformen.

\section{Referenser}

Astvik, Wanja \& Aronsson, Gunnar (1999) „Home care workers as specialists or generalists - quality in work and care", Proceedings/Work, Stress and Health 99, Organization of Work in a Global Economy, 11-13 March 1999, Baltimore, Maryland, USA.

Bergmark, Åke \& Lundström, Tommy (1998) „Metoder i socialt arbete: om insatser och arbetssätt i socialtjänstens individ- och familjeomsorg", Socialvetenskaplig tidskrift, 4, s. 291-314.

Bergmark, Åke \& Lundström, Tommy (2005) »En sak i taget? Om specialisering inom socialtjänstens individ- och familjeomsorgu. Socialvetenskaplig tidskrift, 2-3, s. 125-148.

Bergmark, Åke \& Lundström, Tommy (2007) „Unitarian ideals and professional diversity in social work practice - the case of Sweden". European Journal of Social Work, 10:1, pp. 55-72.

Bergmark, Åke (2001) „Den lokala välfärdsstaten? Decentraliseringstrender under 1990-talet». I M Szebehely (red.), Välfärdstiänster $i$ omvandling, SOU 2001:52. Fritzes: Stockholm.

Blom, Björn (1998) Marknadsorientering av socialtjänstens individ- och familjeomsorg: om villkor, processer och konsekvenser. Umeå: Umeå universitet, Institutionen för socialt arbete. (ak avh)

Blom, Björn (2004) "Specialization in social work practice - effects on interventions in the personal social services", Journal of Social Work, 4:1, pp. 25-46.

Boklund, Ann (1995) Olikheter som berikar? - möjligheter och hinder i samarbetet med socialtjäns-

Lundgren, Blom, Morén \& Perlinski: Från integrering till specialisering... 
tens äldre- och handikappomsorg, barnomsorg samt individ- och familjeomsorg. Stockholm: Stockholms universitet, Institutionen för socialt arbete. (ak avh)

Byberg, Ingrid (2002) Kontroll eller handlingsfrihet?En studie av organiseringens betydelse $i$ socialbidragsarbetet. Stockholm: Stockholms universitet, Institutionen för socialt arbete. (ak avh)

Börjeson, Bengt \& Håkansson, Hans (1990) Hotade, Försummade, Övergivna. Stockholm: Rabén \& Sjögren.

Cambridge, Paul \& Parkes, Tessa Advance (2006) "The Tension between Mainstream Competence and Specialisation in Adult Protection: An Evaluation of the Role of the Adult: Protection Co-ordinator", British Journal of Social Work, 36, pp. 299-321.

Danermark, Berth \& Kullberg, Christian (1999) Samverkan - välfärdsstatens nya arbetsform. Lund: Studentlitteratur.

DiMaggio, Paul J. \& Powell, Walter W. (1991) »The ironcage revisited: Institutional isomorphism and collective rationality in organizational fields». In Walter W. Powell \& Paul J. DiMaggio (eds.), The new institutionalism in organizational analysis. Chicago: The University of Chicago Press.

Doel, M. (1997). Social Work Practise Revisited: Generalist and Specialist Practise. Occasional Monograph, Faculty of Health and Community Care, University of Central England in Birmingham.

Doel, Mark \& Shardlow, Steven M. (1998) The new social work practice. Aldershot: Arena.

Eriksson, Bengt \& Karlsson, Per-Åke (1989) Organisationsformer inom socialtjänstens individoch familjeomsorg, SoS-rapport 1989:39. Stockholm: Socialstyrelsen.

Fuller, Roger \& Tulle-Winton, Emmanuelle (1996) "Specialism, genericism and others: Does it make a difference? A study of social work services to elderly people», British Journal of Social Work, 26:5, pp. 679-698.

Froggett, Lynn (1996) „Instrumentalism, knowledge and gender in social work", Journal of
Social Work Practice, 10:2, pp. 119-127.

Howe, David. (1987) An Introduction to Social Work Theory. Aldershot: Ashgate.

Meyer, John W. \& Rowan, Brian (1991) „Institutionalized organizations: Formal structure as myth and ceremony». In W. W. Powell \& P.J. DiMaggio (eds.) The new institutionalism in organizational analysis. Chicago: The University of Chicago Press.

Minas, Renate (2005) Administrating poverty: studies of intake organization and social assistance in Sweden. Stockholm: Stockholms universitet, Institutionen för socialt arbete. (ak avh)

Mintzberg, Henry (1993) Structures in fives: designing effective organizations. Englewood Cliffs: Prentice-Hall.

Morén Stefan, Blom Björn, Lundgren Minna \& Perlinski Marek (kommande) Specialisering eller integration? En studie av socialarbetares arbetssätt och attityder i tre kommuner. Inskickat artikelmanus.

Perlinski Marek, Blom Björn, Morén Stefan \& Lundgren Minna (kommande) The dialectics between specialisation and integration. Politicians' and managers' views on Swedish social services organisations. Inskickat artikelmanus.

Persson, Märta (1987) "Generalisten gör allt ensam", Socionomen, Nr 1, s. 7-10.

SCB (2008) Årsbok för Sveriges kommuner.

Skogens, Lisa (2001) Olika organisationsformer - olika bemötande? En vinjettstudie av socialsekreterares bemötande och bedömning av socialbidragstagare med begynnande alkoholproblem. Stockholm: Stockholms universitet, Institutionen för socialt arbete. (ak avh)

SOU 1999:97 Slutbetänkande från socialtjänstutredningen.

SOU 1974:39 Socialvården - Mål och medel, Principbetänkande av Socialutredningen.

Socialstyrelsen, (2006) Individ och familjeomsorgen, Lägesrapport 2005.

Stranz, Hugo (2007) Utrymme för variation: Om prövning av socialbidrag. Stockholm: Stockholms universitet, Institutionen för socialt arbete. (ak avh)

Sveriges kommuner och landsting (2005) Kom- 
mungruppsindelning fro.m. 1 januari 2005, tillgänglig på http://www.skl.se/artikel. asp? $\mathrm{A}=11248 \& \mathrm{C}=445$, 2008-04-27.

Söderfeldt, Marie (1997) Burnout. Lund: Lunds universitet, Socialhögskolan. (ak avh)

Wiklund, Stefan (2006) Den kommunala barnavården: om anmälningar, organisation och utfall. Stockholm: Stockholms universitet, Insti- tutionen för socialt arbete. (ak avh)

Wingfors, Stina (2004) Socionomyrkets professionalisering. Göteborg: Göteborgs universitet, Sociologiska institutionen. (ak avh)

Wolk, James L. \& Wertheimer, Mindy R. (1999)

"Generalist practice vs. case management: An accreditation contradiction", Journal of Social Work Education, 35:1, pp. 101-114.

\section{Summary}

\section{From integration to specialization On the organizing of personal social services 1998-2008}

Personal social service (PSS) organizations in Swedish municipalities have changed since the 1980s. From a more integrated model of work, based on generic views, most PSS organizations today have specialized groups with specific tasks. International as well as the Swedish research on organizations for personal social services is limited, thus the knowledge about the consequences of specialization in Sweden is scarce. Before this article, only one total study of how personal social services in all Swedish municipalities are organized has been accomplished. Twenty years later, we can show that only 7 percent of Swedish municipalities have an integrated PSS organization, compared to 48 percent in 1989. Most municipalities have a specialization based on problems, where work groups are organized in order to meet the most common social problems; drug and alcohol abuse, family problems, economic problems etc. Some municipalities, mainly in the major Swedish cities, also have a specialization of tasks and special work groups for intake, investigation and treatment. Plausible reasons for the increased specialization of the PSS are changes in policies, changed economic conditions, professional ambitions and expectations, changed demands, new social problems, and different types of organizational isomorphism. A common argument for increased specialization is that specialized services allow social workers to increase their competence as they have fewer work tasks, and that increased competence will lead to higher quality in service provision. But different specialized units also means that many clients need to establish contact with more social workers than in an integrated organization. Moreover, lack of collaboration and communication between different units can lead to conflicting decisions and insufficient knowledge about the client, since the social worker only works with a limited part of the client's problem situation. 